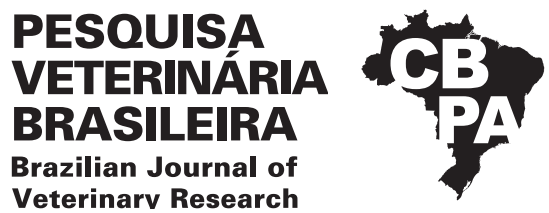

\title{
Welfare during pre-slaughter handling and carcass lesions of beef cattle submitted to different loading densities ${ }^{1}$
}

\author{
Käthery Brennecke ${ }^{2 *}$ (D) Cynthia P. Zeferino², Vando Edésio Soares², \\ Cássia M.B. Orlandi² ${ }^{2}$ Liandra M.A. Bertipaglia ${ }^{2}$, Sarah Sgavioli ${ }^{2}$ (D), \\ Paulo H.M. Dian² and Weberson D.C. Amâncio ${ }^{2}$
}

\begin{abstract}
Brennecke K., Zeferino C.P., Soares V.E., Orlandi C.M.B., Bertipaglia L.M.A., Sgavioli S., Dian P.H.M. \& Amâncio W.D.C. 2020. Welfare during pre-slaughter handling and carcass lesions of beef cattle submitted to different loading densities. Pesquisa Veterinária Brasileira 40(12):985-991. Departamento de Produção Animal, Universidade Brasil, Avenida Hilário da Silva Passos 950, Parque Universitário, Descalvado, SP 13690-000, Brazil. E-mail: kathery.brennecke@universidadebrasil.edu.br

Inadequate pre-slaughter handling conditions can compromise animal welfare and productivity. This study aimed to evaluate the animal welfare (AW) indexes during preslaughter handling and quantify the carcass lesions of beef cattle submitted to different loading densities. A total of 270 Nellore cattle, at 30 months of age, from three farms were used in the study. Each farm presented a different loading density: higher density $\left(500 \mathrm{~kg} / \mathrm{m}^{2}\right)$, intermediate density $\left(450 \mathrm{~kg} / \mathrm{m}^{2}\right)$, and lower density $\left(420 \mathrm{~kg} / \mathrm{m}^{2}\right)$. Three shipments of cattle from each farm with 30 animals each were used in the AW analysis. Ten animals from each shipment were considered for quantification of carcass bruises. The AW indexes were classified according to the five-freedom criterion (physiological, environmental, sanitary, behavioral, and psychological). After slaughter, the carcasses were inspected in the routine line and evaluated for the presence of lesions. Statistically significant differences $(p<0.001)$ were found for all variables studied as a function of AW and bruises. The best AW index and the lowest mean weight of lesions were found at the loading density of $450 \mathrm{~kg} / \mathrm{m}^{2}$. The highest carcass weight was observed at the loading density of $500 \mathrm{~kg} / \mathrm{m}^{2}$. Lesions were found in $100 \%$ of the animals at the loading densities of 500 and $420 \mathrm{~kg} / \mathrm{m}^{2}$. In conclusion, the best AW indexes and the smallest occurrence of bruises were verified at the loading density of $450 \mathrm{~kg} / \mathrm{m}^{2}$. This study confirmed the importance of adequate pre-slaughter handling to ensure cattle welfare and, consequently, greater profitability for producers and slaughterhouses.
\end{abstract}

INDEX TERMS: Welfare, pre-slaughter, carcass, lesions, beef cattle, loading density, animal behavior, transport.

\begin{abstract}
RESUMO.- [Bem-estar durante o manejo pré abate e lesões em carcaça de bovinos submetidos às diferentes densidades de carregamento.] Condições de manejo préabate inadequadas podem comprometer o bem-estar e a produtividade animal. $\mathrm{O}$ objetivo deste estudo foi avaliar os índices de bem-estar animal (BEA) durante o manejo pré-abate e quantificar as lesões em carcaça de bovinos submetidos às diferentes densidades de carregamento. Para isto, foram utilizados 270 bovinos Nelore, aos 30 meses de
\end{abstract}

\footnotetext{
${ }^{1}$ Received on June 15, 2020.

Accepted for publication on September 4, 2020.

${ }^{2}$ Stricto sensu Professional Master's Program in Animal Production, Departamento de Produção Animal, Universidade Brasil, Avenida Hilário da Silva Passos 950, Parque Universitário, Descalvado, SP 13690-000, Brazil. *Corresponding author: kathery.brennecke@universidadebrasil.edu.br
}

idade, provenientes de três fazendas. Cada fazenda apresentou diferente densidade de carregamento: maior densidade $\left(500 \mathrm{~kg} / \mathrm{m}^{2}\right)$, densidade intermediária $\left(450 \mathrm{~kg} / \mathrm{m}^{2}\right)$ e menor densidade $\left(420 \mathrm{~kg} / \mathrm{m}^{2}\right)$. Foram realizados três carregamentos de cada fazenda, compostos por 30 animais cada. Para análise do BEA e quantificação de lesões nas carcaças bovinas foram considerados 10 animais de cada carregamento. Os índices de BEA foram classificados segundo o critério das cinco liberdades (fisiológica, ambiental, sanitária, comportamental e psicológica). Após o abate, as carcaças foram inspecionadas na linha de rotina e avaliadas quanto à presença de lesões. Foram encontradas diferenças significativas $(P<0,001)$ para todas as variáveis estudadas em função do BEA e das lesões. 0 melhor índice de bem-estar e o menor peso médio de lesão foi encontrado na densidade de carregamento de 
$450 \mathrm{~kg} / \mathrm{m}^{2}$. O maior peso da carcaça foi encontrado na densidade de carregamento de $500 \mathrm{~kg} / \mathrm{m}^{2}$. Em $100 \%$ dos animais nas densidades de carregamento de 500 e $420 \mathrm{~kg} / \mathrm{m}^{2}$ foram encontradas lesões. Pode-se concluir que a densidade de carregamento de bovino de $450 \mathrm{~kg} / \mathrm{m}^{2}$ obteve os melhores índices de bem-estar e menor ocorrência de lesões. Este estudo confirma a importância do manejo pré-abate adequado na garantia do bem-estar aos bovinos e, consequentemente, na maior rentabilidade ao produtor e ao frigorífico.

TERMOS DE INDEXAÇÃO: Bem-estar animal, pré abate, lesões, carcaça de bovinos, densidade de carregamento, comportamento animal, bovinos de corte, transporte.

\section{INTRODUCTION}

In 2017, Brazil led the world production of beef, with a commercial herd of 221.8 million head of cattle. Of the total meat produced, $20 \%$ was exported and $80 \%$ supplied the domestic market, guaranteeing a consumption of approximately $37.5 \mathrm{~kg}$ of beef per inhabitant (USDA 2018). Currently, the agricultural sector is undergoing a modernization process related to productive aspects and pre-slaughter logistics aiming to improve animal living conditions and quality of the final product (Mendonça et al. 2016).

Animal welfare (AW) is of paramount importance for ensuring good quality of the meat produced and, therefore, high economic return for producers and slaughterhouses. AW should be considered from the beginning of pre-slaughter handling, which starts on the farm with the separation and fasting of the animals and extends throughout the ante mortem period (Souza 2005).

Practices such as the use of stingers or electric shocks force animals to drive and enter the transport truck during the loading and unloading stage. This type of handling results in large carcass losses resulting from bruises, being more harmful than the distance traveled (Rebagliati et al. 2008). In contrast, when the basic principles of AW are followed - these steps are carried out by professionals who respect animal rights - higher carcass yield and better quality of the final product are obtained (Andrade et al. 2004).

The transport of cattle from the farm to the slaughterhouse is an important pre-slaughter handling step that involves many factors: type of vehicle, loading density, distance and time traveled, road conditions, driver's driving behavior, and temperature. Association between two or more of these factors is determining and can stress the animals and cause bruises on their carcasses (Mendonça et al. 2016). According to Strappini et al. (2009), transport conditions (vehicle design, loading density, climatic conditions, transport time and distance, handlers' training, road conditions, and animal behavior, sex, and breed) can interfere with the level of cattle welfare.

The importance of properly carrying out the transport arises from losses on the quality of the meat produced (Schwartzkopf-Genswein et al. 2012), as it represents the second largest cause of bruises in bovine carcasses, with an index of $33.08 \%$, second only to pre-slaughter handling and vaccination lesions (Moro et al. 2001).

Problems with loading density are commonly cited, but there are few studies on the subject. The Farm Animal Welfare Council establishes a formula for calculating the minimum area occupied by an animal, recommending an average of
$360 \mathrm{~kg} / \mathrm{m}^{2}$ (Knowles 1999). However, from an economic point of view, high animal density transport is expected. In Brazil, the loading density used ranges from 390 to $410 \mathrm{~kg} / \mathrm{m}^{2}$ (Roça 2002); a loading density $>550 \mathrm{~kg} / \mathrm{m}^{2}$ is considered inadequate (Tarrant et al. 1988).

The quantification and classification of bruises present in the carcasses of slaughtered animals is an important indicator of inadequate handling - a fact that can occur at any stage of the process: loading on the farm, transport, unloading at the slaughterhouse, and slaughter (Polizel Neto et al. 2015). However, Braggion \& Silva (2004) consider that lesions in carcasses during transport occur as a result of association of high loading density with greater stress reaction, bruises, large number of falls and other causes such as horns, kicking, and trampling, which are usually linked to handling problems. Bruises are characterized by traumatic lesions caused by vessel bleeding with consequent accumulation of blood and serum in the tissues (Nanni Costa et al. 2006).

Carcass bruises are a way to assess cattle handling and, therefore, are indicative of AW problems. Suppression of the immune system and physiological changes in animals are consequences of stress and may indicate a pre-pathological state (Moberg 1985). Measurements of behavior and physiological evidence are of great value, as they provide data on animal feelings. However, there is not sufficient information in the scientific literature aimed at improving animal welfare. Therefore, developing methods to analyze AW, with emphasis on behavioral characteristics, becomes a great challenge.

Although the stressful effects of pre-slaughter practices on cattle have been widely studied in some regions of the world, the topic still receives limited attention in Latin America (Romero et al. 2013). Thus, little updated information is available in the literature about the impact of transport and pre-slaughter conditions on AW and carcass quality in Brazil. Despite the existence of risk analysis protocols associated with cattle welfare during transport (Marahrens et al. 2011), further studies are needed to identify the harmful effects of these steps on AW and carcass quality. In this way, it is possible to recommend appropriate changes in handling routines that can minimize the biological cost to animals during the pre-slaughter process and improve the product quality (Romero et al. 2013).

In this context, the present study aimed to evaluate the AW indexes during pre-slaughter handling and quantify the carcass lesions of beef cattle subjected to different loading densities.

\section{MATERIALS AND METHODS}

Animals and experimental conditions. The study was conducted in a slaughterhouse located in the interior of the state of São Paulo, Brazil, accredited and supervised by the "Serviço de Inspeção de São Paulo" (SISP). All legal slaughtering recommendations were followed. The procedures involving the animals were approved by the Ethics Committee on the Use of Animals (CEUA) of the "Universidade Brasil", Descalvado campus, state of São Paulo, Brazil, under protocol no. 004/6 - 2016.

A total of 270 castrated male and female, not dehorned, pure and crossbred Nellore cattle at approximately 30 months of age were used in the study. These animals came from three farms (A, $B$, and C) where they were reared on pasture. Three shipments of cattle from each farm with 30 animals each (total 90 animals per 
farm) were used. However, for the experiment's composition and analysis, only 10 cattle per shipment were taken at random, totaling 30 animals per farm.

The average distance traveled to the slaughterhouse was about $55 \mathrm{~km}$ on paved roads. The transport was carried out in the morning's early hours (between 4:30 and 5:30 a.m.) during the winter. According to the Köppen classification, climate in the study region is Cwb (humid subtropical) characterized by dry winters and mild summers, with an average temperature $<22{ }^{\circ} \mathrm{C}$ during the hottest months (Setzer 1966).

Low-capacity, two-axle, livestock, crate trucks were used to transport the cattle. According to Tarrant et al. (1988), the three farms showed an average loading density. However, due to the difference in individual weight between the animals ( 400 to $500 \mathrm{~kg}$, on average), farm $A$ had the highest density $\left(500.1 \pm 14.5 \mathrm{~kg} / \mathrm{m}^{2}\right)$, farm B presented intermediate density $\left(450.8 \pm 26.5 \mathrm{~kg} / \mathrm{m}^{2}\right)$, and farm $\mathrm{C}$ showed the lowest loading density $\left(419.9 \pm 10.9 \mathrm{~kg} / \mathrm{m}^{2}\right)$. Approximate values of 500,450 and $420 \mathrm{~kg} / \mathrm{m}^{2}$ were adopted for farms A, B, and C loading densities, respectively.

According to the procedures required by the current legislation, pre-slaughter and slaughter handling procedures were carried out with rest and a water diet, and were the same for all farms. The cattle were stunned following the requirements of humane slaughter using penetrating captive dart pistols and subsequently hoisted to proceed with the bleeding process and slaughter flow to reduce the economic losses in the carcasses.

The experiment followed a completely randomized design, with three loading densities and ten repetitions per loading, for the characteristics of AW and bruises in bovine carcasses.

Assessment of welfare indexes. The AW indices were evaluated according to the five-freedom criterion (physiological, environmental, health, behavioral, and psychological) proposed by the World Society for the Protection of Animals (WSPA 2009). For each freedom, the farm's condition characteristics, the truck (depending on the transport), and the slaughterhouse were evaluated (Table 1).

Each assessment was carried out by a single strategically positioned evaluator. The evaluator was able to visualize the animals secretly and without interfering with the handlers' activities. For the characteristics analyzed in each location (farm, truck, and slaughterhouse), assessment was carried out following the Welfare Quality ${ }^{\circledR}$ (WSPA 2009) recommendations, with adaptations. Thus, scores from 1 to 5 were generated and averages were obtained.

Evaluation of carcass bruises. The cattle were submitted to a 10-h fast and then transported to the slaughterhouse. The animals belonging to each shipment were allocated and separated from each other and from the rest of the slaughter line to prevent possible occurrence of other types of lesions that could compromise the objectives of this study.

After slaughter, the entire carcass was sawn lengthwise. Each half carcass was weighed and inspected according to Decree no. 9013 of March 29, 2017 (Brasil 2017) and to the Regulation of Industrial and Sanitary Inspection of Products of Animal Origin (Brasil 1997).

Assessment of carcass bruises was performed in the slaughter inspection routine line and followed the criterion described by AusMeat Limited (2001). Purple or blue-red bruises were considered aslesions that occurred within less than 24 hours (Andrade et al. 2008). The lesions were quantified and grouped according to carcass location in forequarter, ribs, and hindquarter, observing the medial and lateral faces of the cranial and caudal parts. Vaccination lesions were also quantified. After counting, the lesions were removed using curved knives, stored in plastic bags with a previously determined weight, and weighed on a digital scale with accuracy of $0.0005 \mathrm{~kg}$.

Statistical analysis. The AW indices and the quantification of bovine carcass bruises were evaluated according to the three different loading densities. The data were processed using the Statistica 12 (StatSoft Power Solutions, Inc., 2014). The model included both the fixed loading density and the random bovine effects. The data were evaluated for normality and homogeneity of variance by residual analysis. For the nonparametric data, comparison of the means was performed by the Kruskal-Wallis test. A significance level of 5\% $(p<0.05)$ was adopted for all statistical analyses.

\section{RESULTS AND DISCUSSION}

Proper handling during the pre-loading and unloading stages and ideal transport conditions are essential in the productive chain of cattle destined for slaughter. However, these stages are still one of Brazil's main cattle handling problems (Brunel et al. 2018). Although there are limitations to assessing AW, indicators in slaughterhouses have the potential to reduce chronic painful conditions to the animals caused by poor handling or damage due to inadequate housing conditions (Grandin 2017).

\section{Table 1. Conditions evaluated for the animal welfare $(\mathrm{AW})$ index in the pre-slaughter handling of beef cattle from three loading densities}

\begin{tabular}{ll}
\hline \multicolumn{1}{c}{ Location } & \multicolumn{1}{c}{ Features* } \\
\hline Farm & Handling - handlers' technique \\
& Handling - loading time \\
& Installation - condition of the cattle chute and syringe \\
& Installation - boarding ramp conditions \\
& Installation - corral floor conditions \\
& Installation - lairage conditions prior to loading \\
& Installation - farm corral floor \\
Truck (during & Handling - driving technique \\
transport) & Handling - truck crate cleaning \\
& Installation - truck crate floor conditions \\
& Installation - crate conditions \\
& Installation - hatch conditions \\
& Installation - partition conditions \\
(adapted from WSPA 2009). & Handling - handlers' technique in unloading \\
& Handling - unloading time \\
& Handling - technique in guiding the animal to the corral \\
& Installation - access ramp \\
& Installation - slaughterhouse corral floor \\
& Installation - shading \\
& Installation - water availability \\
& Installation - sprinkler operation \\
& Installation - gate conditions and lot divisions \\
& Installation - corral space \\
& Handling - handler's technique in conducting slaughter \\
& Installation - animal access to the slaughter ramp \\
& Handling - stunning technique \\
& Installation - stunning box conditions \\
* Evaluation according to the 5-freedom criterion WELFARE QUALITY® & \\
&
\end{tabular}

Pesq. Vet. Bras. 40(12):985-991, December 2020 
Currently, there is no universally accepted protocol for assessing AW. Those available in the scientific literature describe a variety of methods and measures used in slaughter assessment. Although each of them has strengths and weaknesses, it is necessary to consider each slaughter plant's particularities, as the layout of the facilities can lead to difficulties in visual observation and physical measurement of parameters based on welfare. Commercial pressures and the need for speed during the processing step can also prevent these parameters from being measured (Wigham et al. 2018).

In the present study, the highest mean AW index was found at the loading density of $450 \mathrm{~kg} / \mathrm{m}^{2}$, as shown in Table 2 . This result stems from the higher AW rates of the farm, truck, and slaughterhouse at this density.

The scientific literature shows that the most critical, stressful, and bruising stage for the animal is the transport and the association of factors intrinsic to it (Moro et al. 2001, Dalla Costa et al. 2007, Mendonça et al. 2016). Findings of present experiment show that AW at the slaughterhouse obtained the lowest index compared with those on the farm and truck.

Paranhos da Costa (2002) carried out ethological observations of the procedures involved in transporting cattle to the slaughterhouse (from handling on the farm to slaughter), described the handling and facilities conditions, the behavior of the animals, and the frequency, and concluded that detailed studies are needed to detect critical points and establish a cattle handling quality of service program. The way to achieve the necessary cultural change to improve AW, handler safety, and the sector's profitability is through training and knowledge transfer (Huertas et al. 2018).

The lowest AW index on the truck was found at the loading density of $500 \mathrm{~kg} / \mathrm{m}^{2}$ (Table 2). According to Tarrant et al. (1988), high animal loading densities are associated with a greater stress reaction, risk of injury, and number of falls compared with low or moderate loading densities. Their study corroborates the values found in the present study, in which a statistically significant difference was observed between the loading density $(p<0.0001)$ and the worst AW rates on the truck at the densities of 500 and $420 \mathrm{~kg} / \mathrm{m}^{2}$ (Table 2).

Transport to the slaughterhouse compromises the welfare of beef cattle. A tool to measure the AW level is observation of carcass bruises. The frequency of these bruises reflects the transport conditions and, consequently, the animals' welfare, which can be observed to avoid economic losses (Huertas et al. 2018). In this study, the lowest weight of lesions was found at the loading density of $450 \mathrm{~kg} / \mathrm{m}^{2}(p<0.0001$; Table 2$)$.

Huertas et al. (2018) evaluated the unloading conditions associated with the average number of carcass bruises in cattle and found no significant correlation results. Andrade et al. (2008) found lesions in cattle subjected to different transport types as a function of time. They verified a higher proportion of lesions in lots subjected to road transport for more than an hour and distances greater than $70 \mathrm{~km}$, most of them on unpaved roads, but observed a lower proportion of lesions in animals belonging to the lot transported on paved roads over distances up to $50 \mathrm{~km}$. This result was not related to space provided to the animals - the loading density to which the cattle were subject during the transport on crate trucks.

Results of this study also show that the largest number of lesions was found at both high- and low-densities, which corresponded to $100 \%$ of the animals evaluated (Table 3 ). In addition, the average values of tissue removal were 0.81 and $0.80 \mathrm{~kg} /$ bovine for the loading densities of 500 and $420 \mathrm{~kg} / \mathrm{m}^{2}$. Values of 24.30 and $23.40 \mathrm{~kg}$ of removed tissue were obtained for the loading densities considered high and low, respectively, whereas a tissue removal value of $11.18 \mathrm{~kg}$ was verified at the loading density of $450 \mathrm{~kg} / \mathrm{m}^{2}$.

Andrade et al. (2008), when studying cattle carcass bruises caused by transport in the Pantanal region, without considering loading density, observed 82 and $45 \%$ of lesions in batches of cattle transported over distances of $50 \mathrm{~km}$.

Tarrant et al. (1988), Warriss (1990), and Gonzalez et al. (2012) have reported that inappropriate loading densities (either high or low) increase the frequency of falls, lesions, bruises, and mortality, as well as hormonal concentrations due to stress, with consequent reduced meat quality. Tarrant et al. (1988) classify the loading densities of as 600, 400, and $200 \mathrm{~kg} / \mathrm{m}^{2}$ as high, average, and low, respectively. Tarrant \& Grandin (1993) qualify the availability of $1.11 \mathrm{~m}^{2}$ as a high loading density for $500 \mathrm{~kg}$ of body weight, and explain that cattle fall as a result of reduced mobility under these conditions, preventing them from taking their preferred guidance.

According to Mendonça et al. (2016), long vehicles present a more significant centrifugal displacement effect, caused by the vehicle's traction distance - in this case, the front - causing

Table 2. Minimum mean square error (MMSE) of AW indexes in pre-slaughter handling and lesion weight of beef cattle from three loading densities

\begin{tabular}{|c|c|c|c|c|}
\hline \multirow{2}{*}{ Parameters } & \multicolumn{3}{|c|}{ Loading density $\left(\mathrm{kg} / \mathrm{m}^{2}\right)$} & \multirow{2}{*}{ Probability $(P)^{\mathrm{E}}$} \\
\hline & 500 & 450 & 420 & \\
\hline AW farm ${ }^{A}$ & $3.40 \pm 0.10^{c}$ & $3.70 \pm 0.00^{\mathrm{a}}$ & $3.60 \pm 0.03^{b}$ & $<0.0001$ \\
\hline AW truck ${ }^{B}$ & $2.60 \pm 0.10^{c}$ & $3.10 \pm 0.40^{\mathrm{a}}$ & $2.80 \pm 0.00^{\mathrm{b}}$ & $<0.0001$ \\
\hline AW slaughterhouse ${ }^{\mathrm{C}}$ & $2.10 \pm 0.00^{\mathrm{b}}$ & $2.30 \pm 0.20^{\mathrm{a}}$ & $2.10 \pm 0.00^{\mathrm{b}}$ & $<0.0001$ \\
\hline AW mean ${ }^{\mathrm{D}}$ & $2.70 \pm 0.10^{\mathrm{b}}$ & $3.00 \pm 0.20^{\mathrm{a}}$ & $2.80 \pm 0.10^{\mathrm{a}}$ & $<0.0001$ \\
\hline Average carcass weight (kg) & $290.30 \pm 18.60^{\mathrm{a}}$ & $236.50 \pm 37.10^{\mathrm{b}}$ & $236.60 \pm 34.40^{\mathrm{b}}$ & $<0.0001$ \\
\hline Mean weight of lesions (kg) & $0.80 \pm 0.60^{\mathrm{a}}$ & $0.30 \pm 0.40^{\mathrm{b}}$ & $0.80 \pm 1.30^{\mathrm{ab}}$ & $<0.0001$ \\
\hline \multicolumn{5}{|c|}{$\begin{array}{l}\mathrm{A} \mathrm{AW}^{\mathrm{A}} \text { farm = animal welfare on the farm, during pre-slaughter handling, according to the five-freedom criterion, }{ }^{\mathrm{B}} \mathrm{AW} \text { truck }=\text { animal welfare in the truck } \\
\text { (transport stage), during pre-slaughter handling, according to the five-freedom criterion, }{ }^{\mathrm{C}} \mathrm{AW} \text { slaughterhouse }=\text { animal welfare in the slaughterhouse, } \\
\text { during pre-slaughter handling, according to the five-freedom criterion, }{ }^{\mathrm{D}} \mathrm{AW} \text { mean }=\text { average animal welfare during pre-slaughter handling according to the } \\
\text { five-freedom criterion. For AW evaluation and average weight of carcass and lesions, } 10 \text { cattle from each shipment were used; }{ }^{\mathrm{E}} \text { Probability }(\mathrm{P})=\text { probability } \\
\text { of type I error; }{ }^{\mathrm{a}, \mathrm{b}, \mathrm{c}} \text { means followed by the same letter on the line do not differ by the Kruskal Wallis test at } 5 \% \text { probability; average carcass weight = total } \\
\text { carcass weight }(\mathrm{kg}) \text { after removal of lesions; mean weight of lesions = specific lesion quantity (kg). }\end{array}$} \\
\hline
\end{tabular}


greater vibration to the animals, and, as a consequence, greater possibility of bruises or lesions.

Regardless of the loading density, there was predominance of bruises in the forequarter, with a total of 89 lesions (55\%), compared with the hindquarter, with a total of 72 lesions (45\%). In the forequarter, the ribs showed 31 lesions, which represented $35 \%$ of the forequarter's total lesions (Table 3). Huertas et al. (2018), when classifying the prevalence lesion location in the carcass, reported results opposite to those of the present study, with the highest prevalence in the thigh and hip region (29.3\%), followed by the forequarter $(22.4 \%)$, hindquarter (17.3\%), flank (14.1\%), rump (10.1\%), and loin $(6.8 \%)$.

Regarding the total weight of the lesions in different locations in the bovine carcasses, there was no effect of the loading density to the hindquarter $(P=0.2041)$, ribs $(P=0.4989)$, and vaccine site $(p=0.3535)$. However, for the forequarter, there was a statistically significant difference $(p=0.0006)$ with greater and smaller lesion weight at the loading densities of 500 and $450 \mathrm{~kg} / \mathrm{m}^{2}(0.9 \pm 0.3$ vs. $0.4 \pm 0.5 \mathrm{~kg}$, per animal), respectively (Table 4 ).

Andrade et al. (2008), when working with the stunning of cattle slaughtered in the Pantanal region and checking the occurrence of bruises, found a larger number of lesions in the caudal hindquarter and in the hindquarter of the right half-carcasses. However, Ghezzi et al. (2008) reported that the scapula and hindquarters are risk factors for lesions during transport.

Tarrant et al. (1988) observed that the animal's stress level increased according to its location at the rear of the truck crate. The stocking density influenced orientation on the truck. Those authors also observed that loss of balance of the animals was associated with specific driving events, especially braking and cornering. Small losses of balance were recorded at all stocking densities, but large losses of balance, including falling animals, were associated with high loading density.

Andrade et al. (2004) observed that $60.40 \%$ of the bruises in half carcasses in less than 24 h suggest that these lesions had occurred during transport or at the slaughterhouse. This observation corroborates the findings of the present study, since a high rate of lesions was obtained, and the lowest AW rates were verified at the slaughterhouse and on the truck.

Animal bruises have a multifactorial origin. However, there is a consensus in the scientific literature that bruises acquired during the pre-slaughter period occur mainly during the loading, transport, and unloading stages (Dalla Costa et al. 2007), as well as through physical contact, trampling, falls,

Table 3. Number and total weight of lesions in bovine carcasses from three loading densities

\begin{tabular}{|c|c|c|c|}
\hline \multirow{2}{*}{ Parameters } & \multicolumn{3}{|c|}{ Loading density $\left(\mathrm{kg} / \mathrm{m}^{2}\right)^{\mathrm{A}}$} \\
\hline & 500 & 450 & 420 \\
\hline Total number of lesions & 64 & 44 & 53 \\
\hline Number of carcasses with lesion & 30 & 26 & 30 \\
\hline Number of carcasses without lesion & 00 & 04 & 00 \\
\hline Number of carcasses with more than one lesion & 27 & 14 & 17 \\
\hline Number of lesions in the forequarter & 35 & 26 & 28 \\
\hline Number of lesions in the ribs (forequarter) & 10 & 12 & 09 \\
\hline Number of lesions in the hindquarter & 29 & 18 & 25 \\
\hline Percentage of carcasses with lesion ${ }^{\mathrm{B}}(\%)$ & 100 & 87 & 100 \\
\hline Average weight of tissue removed/bovine (kg) & 0.81 & 0.43 & 0.80 \\
\hline
\end{tabular}

${ }^{\mathrm{A}}$ Loading densities refer to the average weight of cattle, from each farm, depending on the truck crate area. For the parameters of lesions in bovine carcasses, 10 animals from each shipment were used. ${ }^{\mathrm{B}}$ The percentage of carcasses with lesion was obtained by the ratio of number of carcasses evaluated to number of carcasses with lesions. Average weight of tissue removed/bovine = Weight of lesion + weight of bruised tissue.

Table 4. Total weight of lesions $(\mathrm{kg})$ in bovine carcasses from three loading densities

\begin{tabular}{|c|c|c|c|c|}
\hline Variable & Loading density ${ }^{\mathrm{A}}\left(\mathrm{kg} / \mathrm{m}^{2}\right)$ & Weight (kg) & $95 \% \mathrm{CI}$ & $p$-value ${ }^{\mathrm{B}}$ \\
\hline \multirow[t]{2}{*}{ Lesion in the forequarter } & 500 & $0.9 \pm 0.3^{\mathrm{a}}$ & $0.8-1.0$ & 0.0006 \\
\hline & 450 & $0.4 \pm 0.5^{b}$ & $0.2-0.6$ & \\
\hline \multirow[t]{3}{*}{ Lesion in the hindquarter } & 500 & $0.8 \pm 0.4^{\mathrm{a}}$ & $0.7-1.0$ & 0.2041 \\
\hline & 450 & $0.8 \pm 0.4^{\mathrm{a}}$ & $0.6-0.9$ & \\
\hline & 420 & $0.9 \pm 0.3^{\mathrm{a}}$ & $0.8-1.0$ & \\
\hline \multirow{2}{*}{ Lesion in the ribs } & 450 & $0.2 \pm 0.4^{\mathrm{a}}$ & $0.1-0.4$ & \\
\hline & 420 & $0.3 \pm 0.4^{\mathrm{a}}$ & $0.1-0.4$ & \\
\hline \multirow[t]{3}{*}{ Vaccination lesion } & 500 & $0.0 \pm 0.0^{\mathrm{a}}$ & $0.0-0.0$ & 0.3535 \\
\hline & 450 & $0.0 \pm 0.1^{\mathrm{a}}$ & $0.0-0.1$ & \\
\hline & 420 & $0.0 \pm 0.0^{\mathrm{a}}$ & $0.0-0.0$ & \\
\hline
\end{tabular}

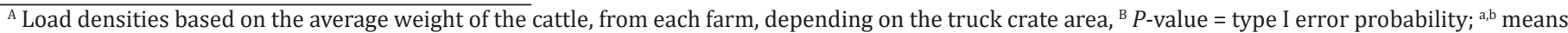
followed by the same letter in the column do not differ by the Kruskal Wallis test at 5\% probability. 
and possible confrontations (Nanni Costa et al. 1999, Grandin 2001). In other words, handling failures and, mainly, the animals' reaction in response to the handlers' aggressiveness result in a greater occurrence of carcass lesions. Care should be taken mainly at the time of separation, as it constitutes a naturally stressful stage. It is necessary to handle the animals according to the welfare requirements so that new routine and balanced normal activities can be reestablished (Paranhos da Costa 2002). Finally, minimizing the stressful effects on cattle to ensure AW and reduce carcass losses is a significant challenge.

\section{CONCLUSIONS}

The best animal welfare indexes and the lowest occurrence of bruises were verified for the cattle loading density of $450 \mathrm{~kg} / \mathrm{m}^{2}$.

The average weight and number of lesions in all treatments confirm the importance of adequate pre-slaughter handling to guarantee cattle welfare, good quality of the meat produced, and higher profitability for producers and slaughterhouses.

The need to adopt professional training programs, supervision and improvement of cattle handling conditions is reinforced.

Conflict of interest statement.- The authors declare having no competing interests.

\section{REFERENCES}

Andrade E.N., Filho Ojeda O., Silva B.S. \& Silva R.A.M.S. 2004. Influência do transporte fluvial em carcaças de bovinos no Pantanal. Corumbá, Embrapa Pantanal, 3p. (Comunicado Técnico, 43).

Andrade E.N., Roça R.O., Silva R.A.M.S., Gonçalves H.C. \& Pinheiro R.S.B. 2008. Prevalência de lesões em carcaças de bovinos de corte abatidos no Pantanal Sul Mato-Grossense transportados por vias fluviais. Ciênc. Tecnol. Aliment. 28(4): 822-829. <https://dx.doi.org/10.1590/S010120612008000400010>

Aus-Meat Limited. 2001. Beef \& veal language. South Brisbane, 4p.

Braggion M. \& Silva R.A.M.S. 2004. Quantificação de lesões em carcaças de bovinos abatidos em frigoríficos no Pantanal Sul-Mato-Grossense. Corumbá, Embrapa Pantanal, p.1-4. (Comunicado Técnico, 45 )

Brasil. 1997. Ministério da Agricultura e do Abastecimento. Secretaria de Defesa Agropecuária - DAS. Departamento de Inspeção de Produtos de Origem Animal - DIPOA. DNT- Divisão de Normas Técnicas. Regulamento da Inspeção Industrial e Sanitária de Produtos de Origem Animal. Brasília, DF. 241p.

Brasil. 2017. Decreto 9013 de 29 de março de 2017. Regulamenta a Lei no 1.283, de 18 de dezembro de 1950, e a Lei no 7.889, de 23 de novembro de 1989, que dispõe sobre a inspeção industrial e sanitária de produtos de origem animal. Disponível em <http://www.planalto.gov.br/ccivil_03/_ato20152018/2017/decreto/D9013.htm> Acesso em 15 jun. 2020.

Brunel H.S.S., Dallago B.S.L., Almeida A.M.B., Assis A.Z., Calzada R.J.B., Alvarenga A.B.B., Menezes A.M., Barbosa J.P., Lopes P.R., González F.H.D., McManus C., Broom D. \& Bern F.E.M. 2018. Hemato-biochemical profile of meat cattle submitted to different types of pre-loading handling and transport times. International Journal of Veterinary Science and Medicine. 6:90-96. <https://dx.doi.org/10.1016/j.ijvsm.2018.04.002>

Dalla Costa O.A., Faucitano L., Coldebella A., Ludke J.V., Peloso J.V., Dalla Roza D. \& Paranhos da Costa M.J.R. 2007. Effects of the season of the year, truck type and location on truck on skin bruises and meat quality in pigs. Livest. Sci. 107(1):29-36. <https://dx.doi.org/10.1016/j.livsci.2006.08.015>
Ghezzi M.D., Acerbi R., Ballerio M., Rebagliati J.E., Diaz M.D., Bergonzelli P., Civit D., Rodríguez E.M., Passucci J.A., Cepeda R., Sañudo M.E., Copello M., Scorzielo J., Caló M., Camussi E., Bertoli J. \& Aba M.A. 2008. Evaluacion de las practicas relacionadas com el transporte terrestre de hacienda que causan perjuicios econômicos en la cadena de ganados y carnes. Sítio Arg Prod Anim, 5: 01-29.

Gonzalez L.A., Schamartzkopf-Genswein K.S., Bryan M., Silasi R. \& Brown F. 2012. Factors affecting body weight loss during commercial long haul transport of cattle in North America. J. Anim. Sci. 90(10):3630-3639. <https://dx.doi.org/10.2527/jas.2011-4786><PMid:22665642>

Grandin T. 2001. Perspectives on transportations issues: the importance of having physically fit cattle and pigs. J. Anim. Sci. 79(E. Suppl.):E201-E207. <https://dx.doi.org/10.2527/jas2001.79E-SupplE201x>

Grandin T. 2017. On-farm conditions that compromise animal welfare that can be monitored at the slaughter plant. Meat Sci. 132:52-58. $<$ https://dx.doi.org/10.1016/j.meatsci.2017.05.004>

Huertas S.M., Kempener R.E.A.M. \& van Eerdenburg F.J.C.M. 2018. Relationship between methods of loading and unloading, carcass bruising, and animal welfare in the transportation of extensively reared beef cattle. Animals, 8(7):119. <https://dx.doi.org/10.3390/ani8070119><PMid:30018193>

Knowles T.G. 1999. A review of the road transport of cattle. Veterinary Record, London, 144(8):197-201. <https://dx.doi.org/10.1136/vr.144.8.197> <PMid:10097341>

Marahrens M., Kleinschmidt N., Di Nardo A., Velarde A., Fuentes C., Truar A., Otero J.L., Di Fede E. \& Dalla Villa P. 2011. Risk assessment in animal welfare - especially referring to animal transport. Preventive Veterinary Medicine, 102(2):157-163. <https://dx.doi.org/10.1016/j.prevetmed.2011.04.010> $<$ PMid:21601298>

Mendonça F.S., Vaz R.Z., Costa O.A.D., Gonçalves G.V.B. \& Moreira S.M. 2016. Fatores que afetam o bem-estar de bovinos durante o período pré-abate. Arch. Zootec. 65(250):279-287. <https://dx.doi.org/10.21071/az.v65i250.500>

Moberg G.P. 1985. Biological response to stress: key to assessment of animal well-being?, p. 27-49. In: Moberg, G.P. Animal Stress. Bethesda: American Physiological Society.

Moro E., Junqueira J.O.B. \& Umehara 0. 2001. Levantamento da incidência de reações vacinais e/ou medicamentosas em carcaças de bovinos na desossa em frigoríficos no Brasil. A Hora Veterinária 21(123):1-5.

Nanni Costa L., Fiego D.P., Dall'Olio S., Davoli R. \& Russo V. 1999. Influence of loading method and stocking density during transport on meat and drycured ham quality in pigs with different halothane genotypes. Meat Sci. 51(4):391-399. <https://dx.doi.org/10.1016/S0309-1740(98)00160-0>

Nanni Costa L., Lo Fiego D.P., Tassone F. \& Russo V. 2006. The relationship between carcass bruising in bulls and behaviour observed during preslaughter phases. Vet. Res. Commun. 30(1):379-381. <https://dx.doi. org/10.1007/s11259-006-0086-9>

Paranhos da Costa M.J.R. 2002. Ambiência e qualidade de carne. Anais do 5o Congresso das Raças Zebuínas-ABCZ, Uberaba, MG, p.170-174.

Polizel Neto A., Zanco N., Lolatto D.C.J., Moreira P.S.A. \& Dromboski T. 2015. Perdas econômicas ocasionadas por lesões em carcaças de bovinos abatidos em matadouro-frigorífico do norte de Mato Grosso. Pesq. Vet. Bras. 35(4):324-328.<https://dx.doi.org/10.1590/S0100-736X2015000400002>

Rebagliati J.E., Ballerio M., Acerbi R., Diaz M., Alvarez M.M., Bigatti F., Cruz J.A., Scitelli L., Ergonzelli P., Gonzalez C., Civit D. \& Ghezzi M.D. 2008. Evaluación de las prácticas ganaderas en bovinos que causan perjuicios económicos en plantas frigoríficas de la República Argentina (2005). REDVET - Revista Electrónica Veterinária 9(10B):1-40.

Roça R.O. 2002. Abate humanitário de bovinos. In: I Conferência virtual global sobre produção orgânica de bovinos de corte. Embrapa Pantanal, Corumba-MS. Brazil.

Romero M.H., Uribe-Velásquez L.F., Sánchez J.A. \& Miranda-de la Lama G.C. 2013. Risk factors influencing bruising and high muscle $\mathrm{pH}$ in Colombian 
cattle carcasses due to transport and pre-slaughter operations. Meat Sci. 95(2):256-263. <https://dx.doi.org/10.1016/j.meatsci.2013.05.014> $<$ PMid:23747620>

Schwartzkopf-Genswein K.S., Faucitano L., Dadgar S., Shand P., González L.A. \& Crowe T.G. 2012. Road transport of cattle, swine and poultry in North America and its impact on animal welfare, carcass and meat quality: a review. MeatSci, 92(3):227-243. <https://dx.doi.org/10.1016/j. meatsci.2012.04.010><PMid:22608833>

Setzer J. 1966. Atlas Climático e Ecológico do Estado de São Paulo. Comissão Interestadual da Bacia Paraná-Uruguai, 61p.

Souza P. 2005. Exigências atuais de bem-estar animal e a sua relação com a qualidade da carne. Embrapa Suínos e Aves. Disponível em <https://www.agencia. cnptia.embrapa.br/Repositorio/exigencias_atuais_de_bem_estar_animal_e_ sua_relacao_com_qualidade_da_carne_000fz75urw702wx5ok0 cpoo6agbfbiwd. pdf> Acesso em 15 jun. 2020.

StatSoft Power Solutions, Inc. (2014). STATISTICA (data analysis software system), version 12. Disponível em:<http://www.statsoft.com> Acesso em 15 jun. 2020.

Strappini A.C., Metz J.H.M., Gallo C.B. \& Kemp B. 2009. Origin and assessment of bruises in cattle at slaughter. Animal, 3(5):728-736. <https://dx.doi. org/10.1017/S1751731109004091><PMid:22444452>
Tarrant P.V. \& Grandin T. 1993. Cattle transport. In: Grandin, T. Livestock Handling and Transport. 1. ed. Cabi International. Wallingford. UK. pp. 109-126

Tarrant P.V., Kenny F.J. \& Harrington D. 1988. The effect of stocking density during 4-hour transport to slaughter on behaviour, blood constituents and carcass bruising in Friesian steers. Meat Sci. 24(3):209-222.<https:// dx.doi.org/10.1016/0309-1740(88)90079-4><PMid:22055952>

USDA. United States Department of Agriculture. 2018. Foreign Agricultural Service. Livestock and Poultry: World Markets and Trade. Available at <https://apps.fas.usda.gov/psdonline/app/index.html\#/app/downloads> Accessed on Jun. 15, 2020

Warriss P.D. 1990. The handling of cattle pre-slaughter and its effects on carcass meat quality. Applied Animal Behaviour Science, Amsterdan, 28 (1/2):171-186. <https://dx.doi.org/10.1016/0168-1591(90)90052-F>

Wigham E.E., Butterworth A., Wotton S. 2018. Assessing cattle welfare at slaughter - Why is it important and what challenges are faced? Meat Sci. 145:171-177. <https://dx.doi.org/10.1016/j.meatsci.2018.06.010> $<$ PMid:29982070>

WSPA Brasil. 2009. World Society for the Protection of Animals. Programa Nacional de Abate Humanitário (Steps): Melhorando o Bem-Estar Animal no Abate. Rio de Janeiro, 2009. 1 CD-ROM, p.33. 